\title{
$\sqrt{ }$ REPORT ON A CASE OF CHRONIC OBLITERATIVE CHOLANGITIS
}

\author{
By Maurice LeE, M.B., B.S., F.R.C.S. \\ Senior Surgeon, Upton Hospital, and Visiting Consulting Surgeon, Iver, Denham and Langley Hospital, Windsor Grou \\ North West Metropolitan Region
}

Chronic obliterative cholangitis is a condition arising from a slowly progressive inflammatory change in the common bile duct, resulting in obliteration of the duct and the development of jaundice. The condition usually, but not necessarily, occurs after cholecystectomy. The symptoms do not arise immediately after the operation but take a variable time to develop, in some cases a few months and in others several years. After the diseased gall bladder has been removed the inflammatory condition in the common bile duct remains and after a lapse of time the condition ends in fibrosis and scarring, causing an obstructive jaundice. Jaundice arising after a gall bladder operation suggests that the bile ducts have been injured at the time of operation, and certainly in about 80 per cent. of cases of benign strictures of the common bile duct surgical trauma is the main cause. A residual stone in the common bile duct accounts for a large proportion of the remaining cases, but undoubtedly obliterative cholangitis is the real cause in many cases attributed to trauma or to a remaining stone in the common bile duct.

There are several clinical signs helpful in the diagnosis of these cases. In some cases, prior to the cholecystectomy, the patient may have complained of shivering attacks associated with fever, and in addition attacks. of a mild degree of jaundice, indicative of Charcot's intermittent fever. At the time of the cholecystectomy, when the common bile duct is drained, the nature of the biliary drainage is indicative of a cholangitis, the biliary fluid being sandy, muddy or gritty. Furthermore, there may be some degree of slowness in the closure of the biliary fistula when the $T$ tube has been removed; instead of the fistula drying up in 48 to 72 hours, there may be drainage of bile for two to three weeks after the tube has been taken out. Such signs as these should give rise to suspicion of the existence of an active condition in the bile duct and the possibility of the development, in the course of time, of an obliterative cholangitis.
The obliterative changes which are the find results of the inflammatory process vary in the length in the common bile duct. They have bee described as involving the whole length of the duct and even extending into the intra-hepation ducts. In the case described below, the retro duodenal portion of the common bile duct only wæ involved.

Chronic obliterative cholangitis usually occurs in cases of neglected gall bladder disease whers the inflammation has spread from the gall bladder. into the ductal system. Judd states that when. stricture arises from this condition the obstructor is usually not complete, and this was confirme ${ }^{\mathbb{P}}$ in the case to be described, in which the stools never absolutely clay-coloured. $\mathrm{He}$ also states that when the common duct is opened at the seconf operation, there is not the rush of bile that is see in cases of traumatic stricture. This again was observed in the case described below.

\section{Case History}

Mrs. L. B., aged 66 years, was first seen in October 1952. She gave the usual history of ' gall bladder trouble,' such as pain in the right subcostal region for years, the pain going through to the back. In addition, she said she suffered. from shivering attacks with fever now and agairo Four years previously she had an attack of yellow jaundice.

A cholecystogram (double dose dye) showed poor concentration of the dye in the gall bladde and a number of partly calcified gall stones. I November 1952, a diseased gall bladder containing numerous stones was removed. The commot bile duct was explored at the time of operation and because of the presence of numerous stones in the gall bladder, it was decided to do a cho langiogram on the table to make sure of the patency of the common bile duct into the duof denum (Fig. 1). This showed the dye running into the duodenum with the minimum of hold-up in the common bile duct. This was very satios 


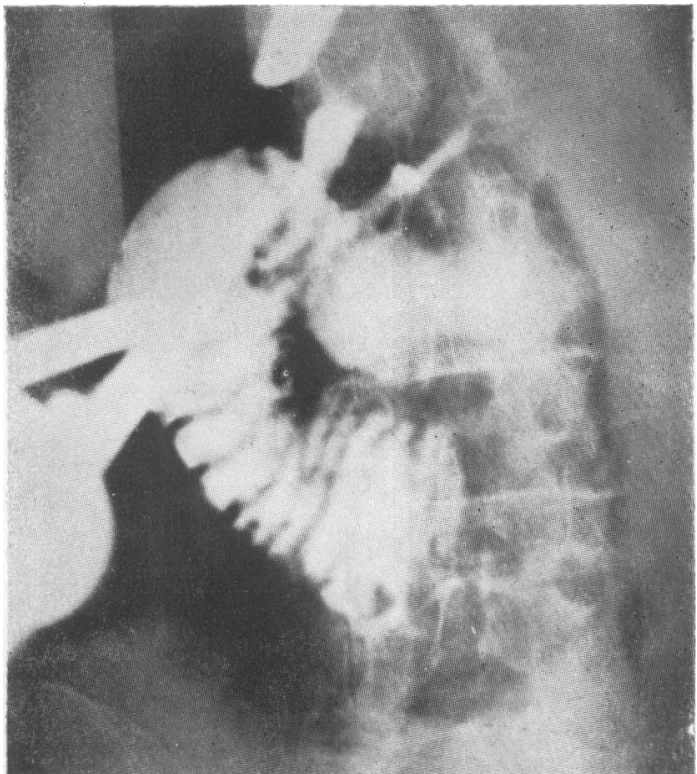

FIG. I.-Cholangiogram done at the first operation when the gall bladder was removed. This shows the dye running into the duodenum and running back into the pyloric end of the stomach. There is no hold up whatsoever in the common bile duct.

factory, as it gave additional evidence (besides the exploration of the common bile duct by means of probes and washing it out) that there was no obstruction from possible residual stones in the terminal part of the duct.

After operation, the patient continued to pass muddy, dirty bile through her drainage tube in the common bile duct, and because of this the tube was kept in longer than usual. Eventually the tube was taken out, but she still discharged bile through the fistula left from the drainage tube for a further 10 days.

Approximately six months after her operation she presented herself in the Outpatients' Department with jaundice. This was mild in nature and was associated with generalized pruritus. The stools were slightly coloured. She was put on testosterone $5 \mathrm{mg}$. t.d.s. to relieve her pruritus, with great benefit. Further investigations were carried out, the results of which are given below and compared with the post-operative investigations.

On September 9, I953, the second operation was carried out. After the common bile duct was exposed and opened, a fibrous stricture was found to be present in the duct, commencing just above the duodenum and extending behind the duodenum. Although it was possible to pass a probe or a bougie upwards into the liver, the duct down-

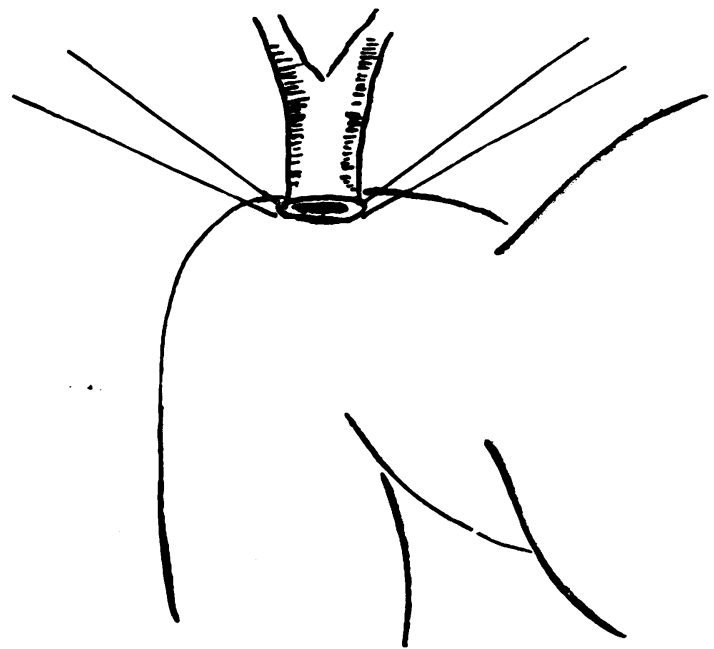

FIG. 2.-Diagram showing the implantation of the common bile duct into the first part of the duodenum (diagrammatic, after Maingot).

wards was impassable. The common bile duct itself at the time of operation was not unduly distended and when opened the bile did not gush $\vec{\bullet}$ out, thus suggesting the presence of an incomplete $\mathrm{F}$ blockage. The common bile duct was transected just above the duodenum and the upper end was re-implanted into the duodenum (Fig. 2). Following this the patient made an uneventful recovery. Three days after the re-implantation the jaundice began to subside and the first stool passed after operation was normal in colour. She was discharged from hospital on September 29, 1953.

The following are the investigations which were carried out :

\begin{tabular}{|c|c|c|}
\hline & $\begin{array}{c}\text { Sept. 4, } \\
\text { I } 953 \\
\text { (just before } \\
\text { operation) }\end{array}$ & $\begin{array}{c}\text { Sept. } 29, \text { I } 953 \\
\text { (during post- } \\
\text { operative period) }\end{array}$ \\
\hline $\begin{array}{l}\text { Alkaline phosphatase } \\
\text { Thymol turbidity } \\
\text { Colloidal gold } \\
\text { Serum bilirubin }\end{array}$ & $\begin{array}{l}\text { I } 8.7 \text { units } \\
1.5 \text { units } \\
\text { negative } \\
8.0 \mathrm{mg} . \% \\
30 \mathrm{mg} . \%\end{array}$ & $\begin{array}{c}4.0 \text { units } \\
\text { I.5 units } \\
\text { } 0000 \\
\text { bilirubin } 1.8 \mathrm{mg} . \% \\
\text { direct reaction } \\
\text { delayed } \\
25 \mathrm{mg} . \%\end{array}$ \\
\hline
\end{tabular}

\section{Summary and Conclusions}

Although the vast majority of cases of jaundice coming on after a gall bladder operation can be $\mathbb{D}$ attributed to injury to the common bile duct, $\stackrel{\text { ? }}{?}$ obliterative cholangitis resulting in stenosis must be borne in mind.

A muddy and gritty biliary drainage should 
suggest that the common bile duct has to accommodate an infective bile which can set up inflammatory changes in its walls. In addition, a history prior to cholecystectomy of attacks of intermittent fever (Charcot type) is suggestive of duct changes which may end in obliterative cholangitis. In cases where numerous stones are found at cholecystectomy, or where the bile when examined is gritty, muddy or dirty-looking, a cholangiogram is worth carrying out on the table. it makes doubly sure (in addition to exploring the common bile duct) that there is no obstruction of the duct at its entrance to the duodenum. In addition it gives the surgeon the satisfaction of knowing that there is no question of injury to the duct should jaundice develop subsequent to th cholecystectomy.

Chronic obliterative cholangitis may develop if neglected gall bladder cases, and cholecystectom $\overrightarrow{F^{*}}$ should be advised in the early stages of chole cystitis in order to prevent this pathological condition developing.

\section{BIBLIOGRAPHY}

JUDD, E. S. (1926), Ann. Surg., 84, 404.

WILSON, E. G. (1939), Surg. Gynec. $\mathscr{E}^{\circ}$ Obst., 68, 288.

WALTERS, W., and HEIM, D. J. (1946), Proc. Mayo Clinict 377, 2 r.

\section{PERIPHERAL VASCULAR DISORDERS}

\section{(Postgraduate Medical Journal)}

Price: 3s. 8d., post free

\author{
THE INVESTIGATION OF PERIPHERAL \\ VASCULAR DISORDERS \\ Peter Martin, V.R.D., M.Chir., F.R.C.S. (Ed.) \\ PERIPHERAL ARTERIOGRAPHY AND \\ AORTOGRAPHY \\ Robert E. Steiner, M.B., Ch.B., D.M.R., \\ F.F.R., and David Messent, M.B., F.R.C.S
THE MEDICAL MANAGEMENT OF OBLITERATIVE ARTERIAL DISEASE OF THE LEGS
Robert Semple, M.D., M.R.C.P.

\author{
RAYNAUD PHENOMENON \\ R. P. Jepson, F.R.C.S. \\ COLlateral CIRCULATION IN THE \\ LIMB \\ C. J. Longland, M.V.O., M.S., F.R.C.S.
}

\section{SYMPATHECTOMY AND PALLIATIVE OPERATIONS FOR OCCLUSIVE ARTERIAL DISEASE}

A. J. Slessor, M.V.O., F.R.C.S.

BLOOD VESSEL GRAFTING

C. G. Rob, M.C., M.Chir., F.R.C.S.

Published by

THE FELLOWSHIP OF POSTGRADUATE MEDICINE

60, Portland Place, London, W.1.

Bibliography continued from page i 83-F. P. Crawford, M.D., M.R.C.P., D.P.M.

HILL, D (1050), in 'Electro-encephalography,' edited by D. Hill and G. Parr, Macdonald, London.

HILL, D. (1952), Electro-enceph. clin. Neurophysiol., 4, 4 I 9.

KREE.ZER, G. (1937), Proc. Amer. Ass. ment. Def., 42, ii, 130.

LEWIS, A. J. (1950), in F. W. Price's 'Textbook of the Practice of Medicine,' 8th Edn., O.U.P.

MINISTRY OF HEALTH AND NATIONAL HEALTH SERVICE MEMORANDUM (1950), 'The Development of Consultant Services,' H.M.S.O.

MULLINS, C. (1953), The Listener, 49, 17 I.

PALMER, H. (1952), Brit. med. F., ii, 1633.

PATERSON, SiR A. (I95I), 'Paterson on Prisons,' edited by S. K. Buck, Frederick Muller Ltd., London.

PICKWORTH, F. A. (1952), Brit. med. F., ii, I414. REY, J. H., POND, D. A., and EVANS, C. C. (1949), Proc. Rö

STEWART, I. MCD. G. (1953), Lancet, i, I261.

SYMONDS, C. P. (194I), Proc. Roy. Soc. Med., 34, 289.

TERMAN, L. M., and MERRILL, M. A. (I937), 'Measuring Intelligence,' Harrap.

TINBERGEN, N. (I95I), 'The Study of Instinct,' Oxfofed Clarendon' Press.

VAN DEN BERGH, T. E. (1954), Lancet, i, I60, and subsequeent correspondence.

WOODWORTH, R. S., and MAROUIS, D. G. (1949), 'Psych logy: A Study of Mental Life,'Methuen.

ZELMANOWits, J. (1953), Proc. Roy. Soc. Med., 46, 93 I. 